\title{
INFEKCIJOS IR ANTIBIOTIKŲ REIKŠMĖ SUSIRGIMUI ASTMA BEI ASTMOS GYDYMUI
}

\author{
Dr. Vilija Bubnaitiene \\ KMU Vaikų ligų klinika
}

\begin{abstract}
REIKŠMINIAI ŽODŽIAI: astma, kvépavimo takų infekcijos, antibiotikai.
SANTRAUKA. Astmos ir kitų atopinių ligų paplitimas per pastaruosius 3 dešimtmečius grèsmingai padidèjo visame pasaulyje. Kita pasaulinè visuomenès sveikatos problema - vis dažnesnis nereikalingas antibiotikų skyrimas, ypač vaikams, virusinèms ar nereikšmingoms bakterinėms ligoms gydyti. Vis daugèja tyrimais pagristų irodymu, kad sergamumas astma ir kitomis atopinėmis ligomis didejja dèl per dažno antibiotikų vartojimo ir mažẻjančio mikrobinių antigenų stimuliuojamojo poveikio bręstančiai imuninei sistemai, reikalingo, kad susiformuotų neatopinis Th1 tipo atsakas, ypač pirmaisiais gyvenimo metais. Kvèpavimo takų infekcija, ypač bakterine, pirmaisiais gyvenimo metais padedanti subrandinti vaiko imuninę sistemą ir apsisaugoti nuo astmos, vèliau gali tapti susirgimo astma priežastimi arba sukelti astmos paūmejjimą jau šia liga sergančiam pacientui. Tokiais atvejais būtinas tinkamas antibakterinis gydymas. Vis dèlto antibiotikais astma sergančiu pacientų nederėtu gydyti rutiniškai. Antibakterinis gydymas skirtinas tik tiems astma sergantiems pacientams, kuriems pasireiškia klinikinių, biologinių ir/ar radiologinių bakterinès infekcijos požymių.
\end{abstract}

\section{İŽANGA}

Astma ir kitos alerginès ligos - aktuali visuomenès sveikatos problema visame pasaulyje. Alergija maistui, kuri dažniausiai prasideda kūdikystėje ir kliniškai pasireiškia atopiniu dermatitu, yra pirmasis atopijos ženklas. Ilgainiui įkvepiamieji alergenai tampa reikšmingesni negu maisto, ir atopiškas vaikas suserga alerginiu rinokonjunktyvitu, alergine astma. Ši natürali alergijos klinikiniu formų eiga vadinama „atopijos maršu“. Epidemiologiniai tyrimai, atlikti per pastaruosius du tris dešimtmečius, rodo, kad atopiniu ligu paplitimas padidejo tiek Vakarų, tiek besivystančiose šalyse. Atopinių ligụ paplitimo padidèjimas toks stulbinantis, kad prabilta apie gresiančią alergijos pandemiją. Pavyzdžiui, nuo 1980 iki 1994 m. bendrasis astmos paplitimas JAV išaugo 75 proc., 5-14 m. amžiaus vaikų grupejje -74 proc., vaikų iki $4 \mathrm{~m}$. amžiaus - 160 proc. [1]. Nors daugiausia akcentuojamas astmos paplitimo didejjimas, bet atopinio dermatito ir alerginio rinito dažnumas taip pat didèja. Naujausiais duomenimis, astma diagnozuota 10 proc. pasaulio vaikụ ir 5 proc. suaugusiujug, atopinis dermatitas $-10-12$ proc. pasaulio vaiku ir 0,9 proc. suaugusiụjų, alerginiu rinitu serga nuo 1,4 iki 39,7 proc. ịvairiu pasaulio šaliu gyventoju [2, 3]. Prognozuojama, kad $2010 \mathrm{~m}$. astma sirgs apie 6 proc. visų žemès gyventojų, o 50 proc. iš ju bus jauni, darbingo amžiaus žmonès.

Kita aktuali pasaulinè visuomenès sveikatos problema - vis didejjantis nereikalingas antibiotikų, ypač plataus poveikio, vartojimas virusinèms ar nereikšmingoms bakterinems ligoms gydyti. Antibiotikai per laikotarpi nuo jų atradimo išgelbejo daugybę gyvybių. Deja, grėsmingos netinkamo antibiotikų vartojimo pasekmės, tokios kaip vis didèjantis bakteriju atsparumas; imunosupresija; normalios organizmo mikrofloros pusiausvyros pažeidimas ir dèl to didejjantis imlumas bakterinèms, grybelinėms, virusinėms bei parazitinėms ligoms; superinfekcijos; pakartotinis beveik išnaikintu infekcijų protrūkis verčia naujai pažvelgti i̇ šiuos stebuklingus vaistus. Dar viena nereikalingo antibiotiku vartojimo pasekmè, anot mokslininkụ, yra ir didejjantis alerginiu ligu paplitimas.

\section{INFEKCIJOS IR ANTIBIOTIKU ITAKA ASTMOS BEI KITŲ ATOPINIŲ LIGŲ ATSIRADIMUI}

Atopinès ligos - išsiderinusio imuninio atsako epidemija? Alerginių ligų pandemijos priežastys kol kas nèra visiškai aiškios. Šeiminè alerginiụ ligų anamnezè svarbus skatinamasis atopinių ligų veiksnys (genetiniai veiksniai atopinių ligu pasireiškimą lemia $5-75$ proc. atvejų), bet genetinè industriniu šaliu populiacijos struktūra per pastaruosius du dešimtmečius reikšmingai nepakito, taigi vien genetinių veiksniụ ịtaka staigaus atopinių ligụ plitimo didẻjimo paaiškinti negalima.

Keletu tyrimų, atliktu žlugus komunistinei sistemai, nustatyta, kad atopiniu ligu paplitimas Rytu ir Vakaru Europoje labai skiriasi. Šienligès, astmos, kvejpavimo taku hiperreaktyvumo ir atopinès sensibilizacijos, vertintos alerginiais odos méginiais, paplitimas Vakaru Vokietijos 9-11 metu vaiku grupèje buvo statistiškai reikšmingai didesnis nei Rytų Vokietijos [4]. Reikšmingai didesnis atopinès sensibilizacijos paplitimas buvo nustatytas ir Švedijoje gyvenančiu 10-12 metụ vaikụ 
grupejje, palyginti su to paties amžiaus vaikais, gyvenančiais Estijoje ir Lenkijoje [5]. Panašūs skirtumai pastebėti ir lyginant kitas Rytų bloko bei Vakarų šalis. Praejjus keleriems metams, atopinių ligu paplitimas Rytų bloko šalyse ėmè didèti ir beveik susilygino su Vakarų šalių. Šie epidemiologiniai stebejjimai leido daryti prielaidą, jog reikšmingiausi veiksniai atopinėms ligoms plisti buvo urbanizacija ir vakarietiškas gyvenimo būdas, kurių padariniai - maisto ir oro alergenų pagausejjimas aplinkoje, oro taršos padidejjimas, higienos sąlygų pagerẻjimas, mažos šeimos, vakcinavimas, vis didejjantis antibiotikų vartojimas ir kt. Viena iš teorijų, aiškinančių atopinių ligų plitimą, sulaukusi daugiausia dèmesio yra „higienos hipotezè“. „Higienos hipotezès“ šalininkai teigia, kad atopinès ligos dažnẻja dẻl susilpnẻjusio mikrobinių antigenų stimuliuojamojo poveikio bręstančiai imuninei sistemai, reikalingo, kad susiformuotu neatopinis Th1 tipo atsakas, - tai pasekmè vis gerejjančių higienos sąlygų, gyvenimo industrinèse bendruomenèse, o ne ūkiuose, dažno vakcinų ir antibiotikų vartojimo (1 pav.) [6].

Th1/IFN- $\gamma$ tipo imuninis atsakas, lemiantis IgG gamybą ir neutrofilini uždegimą, dažniausiai nukreiptas prieš intraląstelinius patogenus - bakterijas ir virusus. Th2/IL-4 tipo imuninis atsakas, lemiantis alerginių antikūnų - reaginų (IgE, IgG4) sintezę ir eozinofilinį uždegimą, dažniausiai nukreiptas prieš ekstraląstelinius patogenus, ypač parazitus, pavyzdžiui, niežų erkes, helmintus, o esant atopijai, t. y. genetiniam polinkiui reaguoti i ịprastines aplinkos medžiagas Th2/IL-4 tipo atsaku, dar ir prieš ịprastines aplinkos medžiagas, tokias kaip žiedadulkès, dulkès, pelèsiai, epiderminès gyvūnų molekulès.

Mokslininkai mano, kad nuolat veikiant patogenams palaikoma pusiausvyra tarp Th1 ir Th2 tipo imuninio atsako. Išsiderinus šiai sistemai ir ịsivyravus vieno tipo atsakui, daugejja tam tikro pobūdžio ligų: vyraujant Th1 tipo atsakui - autoimuninių ligų, o vyraujant Th2 tipo atsakui - alerginių.

\section{TH1 IR TH2 TIPO IMUNINIO ATSAKO STIMULAI}

Th1 tipo imuninio atsako stimulai. Tik ką gimusio naujagimio imuninis atsakas yra labiau Th2 tipo. Ma-

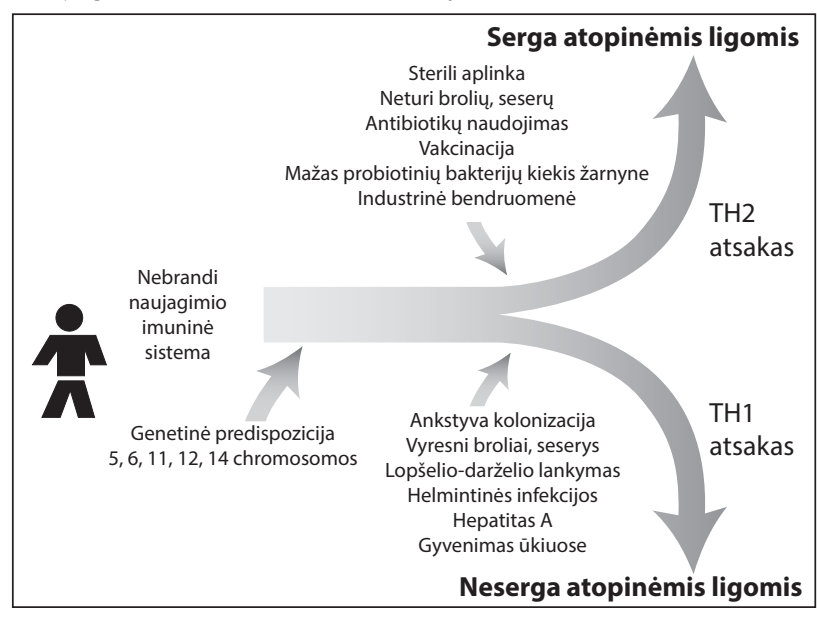

1 pav. ATOPINIU LIGŲ PAPLITIMO DIDĖJIMO PRIEŽASTYS - „HIGIENOS HIPOTEZË" noma, kad rekurentinès infekcijos, ypač pirmaisiais gyvenimo metais, skatindamos Th1 tipo citokinu gamybą, padeda subręsti $\mathrm{T}$ ląsteliniam imuniniam atsakui iki darnaus fenotipo. Galutine pusiausvyra tarp Th1 ir Th2 fenotipuc nusistovi tik 4-5 gyvenimo metais.

Tyrimais, kuriais analizuotas ryšys tarp infekcijų ankstyvuoju gyvenimo periodu ir atopijos rizikos, nustatyta, kad tiek kvejpavimo takų, tiek virškinamojo trakto infekcijos, gali skirtingai prisideti prie imuninès sistemos subrendimo. Perspektyviaisiais tyrimais, kuriuose dalyvavo vaikai, sergantys patvirtintu RSV bronchiolitu, nustatyta, kad, palyginti su juo nesirgusiais vaikais, per pirmuosius 4 gyvenimo metus kartotiniai švokštimo epizodai esti dažnesni, kvėpavimo funkcija blogėja, kvėpavimo takų reaktyvumas didejja, o tarp bronchiolito kūdikystëje ir atopinès sensibilizacijos mokykliniame amžiuje yra ryšys [7, 8]. Kita vertus, daug epidemiologinių tyrimų rodo, kad kartotinės kitų virusų sukeltos ir bakterinès kvèpavimo taku ligos, persirgtos ankstyvuoju vaikystės laikotarpiu, sumažina atopinių ligų riziką. Perspektyviuoju Tukseno kohortiniu tyrimu nustatyta, kad vaikų, per pirmuosius trejus gyvenimo metus sirgusių kvėpavimo takų liga, pavyzdžiui, tracheobronchitu ar pneumonija, atopinè sensibilizacija ir bendrasis IgE kiekis serume vèliau buvo mažesni [9]. Gvinèjos kohortinio tyrimo, kurio metu stebèti vaikai nuo 0-6 metų iki 18 metų, rezultatai rodo, kad tymais sirgę vaikai perpus rečiau turejjo atopinę sensibilizaciją nei tie, kurie buvo skiepyti ir tymais nesirgę [10]. Japonijoje atlikto tyrimo duomenimis, tarp tuberkulino méginio reaktyvumo mokykliniame amžiuje ir astmos dažnumo yra atvirkštinis ryšys, o tai rodo, jog skiepijimas BCG vakcina ir teigiama reakcija ị tuberkuliną gali apsaugoti nuo susirgimo astma [11].

Itin reikšmingai imuninès sistemos brendimą veikia ir nuo atopinių ligų apsaugo virškinamojo trakto bakterijos ir juc produktai. Svarbi tiek normaliu simbiontu (laktobakterijų, bifidobakterijų), tiek patogenų mikrobinè stimuliacija. Nustatyta, kad teigiama serologinè reakcija i vieną ar daugiau mikrobu (Toxoplasma gondii, Helicobacter pylori, HAV) buvo atvirkščiai susijusi su šienlige, alergine astma ir atopine sensibilizacija [12]. Vis daugeja įrodymų, kad nepatogeninè mikroflora (probiotikai) gali apsaugoti nuo alerginių ligų pasireiškimo. Buvo pastebèta skirtumų tarp alergiškų ir nealergiškų vaikų žarnyno mikrofloros, ịskaitant mažesnị kiekị probiotinių bakterijų (bifidobakterijų, laktobakterijų) ir didesni kieki patogeninių bakterijų (S. aureus, Clostridium difficile ir kt.). Nors mechanizmai nèra aiškūs (manoma, kad gramteigiamų virškinamojo trakto bakterijų poveikis bręstančiai imuninei sistemai gali reikštis per Toll tipo receptorius (TLR), pvz.: TLR2, TLR4 ir TLR9, kurie prisideda prie Th2 tipo atsako slopinimo), nustatyta, kad didesnè probiotinių bakterijų kolonija sveiko kūdikio organizme gali skatinti maisto toleravimą ir taip mažinti alerginių ligu riziką. Neseniai įrodyta, kad probiotikų vartojimas paskutinemis nèštumo savaitėmis ir pirmaisiais 6 gyvenimo mènesiais statistiškai reikšmingai sumažino riziką susirgti atopiniu dermatitu vienerių ir ketverių metų amžiuje [13]. 
Th2 tipo imuninio atsako stimulai. Vienas iš vakarietiškos gyvensenos bruožų - labai paplitęs antibiotiku vartojimas nereikšmingoms ligoms gydyti. Antibiotiku išrašoma tik atsiradus pirmiesiems kvèpavimo takų ligos simptomams. Mažų vaikų gydymas antibiotikais ne tik sumažina nereikšmingų bakterinių ligų dažnumą, bet ir išderina normalią žarnyno mikroflorą: taip sukuriama mikroaplinka, kuri yra mažiau efektyvi skatinant Th1 tipo imunini atsaką. Mažejant Th1 atsako stimulų, susidaro sąlygos išlikti Th2 tipo atsakui, esančiam gimus. Šią koncepciją patvirtina tyrimai, kuriais nustatyta, kad šalyse, kuriose atopinių ligų paplitimas mažesnis, gyvenančių kūdikių žarnyne vyrauja laktobakterijos, o gyvenančių tose, kur atopinių ligų paplitimas didesnis, aerobinès gramneigiamos bakterijos ir S. aureus [14, $15]$.

Ryšys tarp antibiotiku vartojimo ir susirgimo astma buvo tiriamas daugelio mokslininkų. Oksfordo bendrosios praktikos klinikose ir kabinetuose atliktu retrospektyviuoju tyrimu, kurio metu buvo peržiūrètos ambulatorinès kortelès, nustatyta, kad vaikams, gavusiems bet kokių antibiotiku iki dveju metų, nepriklausomai nuo klinikinių indikacijų, šienligès ir egzemos rizika padvigubejo; cefalosporinai ir makrolidai buvo susiję su didesne rizika sirgti atopinems ligoms nei penicilinai [16]. J. H. Droste su kolegomis nustatè, kad astma, šienlige ir egzema statistiškai reikšmingai dažniau sirgo vaikai, gydyti antibiotikais pirmaisiais gyvenimo metais ir turèję genetini polinkị i atopines reakcijas [17]. M. Wjst su kolegomis taip pat nustatè ryši tarp didejjančio antibiotikuc kursų skaičiaus ir didejjančios astmos rizikos [18].

\section{INFEKCIJOS IR ANTIBIOTIKŲ VAIDMUO GYDANT ASTMA}

Virusų, kiek rečiau bakterijų sukelta kvėpavimo takų liga svarbi ne tik astmos atsiradimui, bet ir eigai. Kaip minèta ankstesniame skyriuje, kvėpavimo taku infekcija, ypač bakterinè, pirmaisiais gyvenimo metais gali padèti subrandinti vaiko imuninę sistemą ir apsaugoti nuo astmos. Tuo tarpu vyresniame amžiuje ji, ypač jei sukèlëjai netipiniai, gali tapti astmos priežastimi arba sukelti jau sergančio astma paciento ligos paūmejjimą (2 pav.). Vis dèlto antibiotikų neturètu būti skiriama rutiniškai. Antibakterinis gydymas skirtinas tik tiems astma sergantiems pacientams, kuriems yra klinikinių, biologinių ir/ar radiologinių bakterinès infekcijos požymių: sinusitas, pneumonija ir kt. Daugeliu klinikinių tyrimų nustatyta, kad rutininis astmos paūmèjimų antibakterinis gydymas nèra naudingas, kadangi daugumą astmos paūmèjimų, ypač vaikystèje, sukelia virusinė infekcija. S. L. Johnston su kolegomis, taikydami PCR ir pasèlių metodus, nustatè, kad net 80 proc. švokštimo ar PEF sumažejjimo epizodų 9-11 m. astma sergantiems vaikams sukèlè virusai: rinovirusai (61 proc. atvejų), koronavirusai (16 proc.), influenza virusai (9 proc.), parainfluenza virusai (9 proc.) ir RSV (5 proc.) [19].

\section{ASTMA IR BAKTERINĖS KVËPAVIMO TAKŲ INFEKCIJOS}

Dažniausiai identifikuojami bakteriniai sukèlèjai astma sergantiems pacientams yra šie: $H$. influenzae, S. pneumoniae, M. catarrhalis, M. pneumoniae, C. pneumoniae ir S. aureus [20]. Reikètú turèti galvoje, kad astma sergančio paciento viršutiniai kvèpavimo takai gali būti kolonizuoti potencialiai patogeninių bakterijų, todèl bakterinès ligos diagnozę daugeliu atvejų sunkoka patvirtinti neturint kokybiško apatinių kvėpavimo takų pasėlio.

Vis daugèja ịrodymų apie tokių netipinių sukèlejjų kaip C. pneumoniae ir M. pneumoniae sukeltos ūminès infekcijos reikšmę tiek vaikų, tiek suaugusiųjų astmos patogenezei. Nustatyta, kad ūminès C. pneumoniae ir M. pneumoniae infekcijos gali ne tik paūminti jau esamos astmos eigą, bet ir skatinti astmos pradžią nepatyrusiems astmos simptomų, bet genetiškai linkusiems ja sirgti asmenims [21, 22].

Jau yra ir netipiniu bakterijų sukeltos létinès infekcijos įrodymų, nustatyta, kad ji turi įtakos nuolatinès (persistuojančios) astmos patogenezei paauglysteje bei suaugus. Tiek C. pneumoniae, tiek M. pneumoniae gali ilgai išlikti kvėpavimo takuose. Ypač daug rašoma apie chlamidijų sukeliamas lètines ligas audiniuose taikiniuose. Atliktu tyrimų rezultatai rodo, kad egzistuoja ryšys tarp lètinès netipinių bakterijų sukeltos ligos ir nekontroliuojamos astmos [21, 23, 24]. Be to, nustatyta, kad astma sergantys pacientai šiems netipiniams sukèlejams imlesni nei astma nesergantys: nuolatine (persistuojančia) astma sergantiems pacientams statistiškai reikšmingai dažniau patvirtinama lètinè $C$. pneumoniae ir/ar M. pneumoniae infekcija nei astma nesergantiems kontrolinès grupès pacientams [23, 25, 26].

Blogai kontroliuojama astma, nors ir gydoma labai didelèmis inhaliuojamųjų ir geriamųjų steroidų dozé-

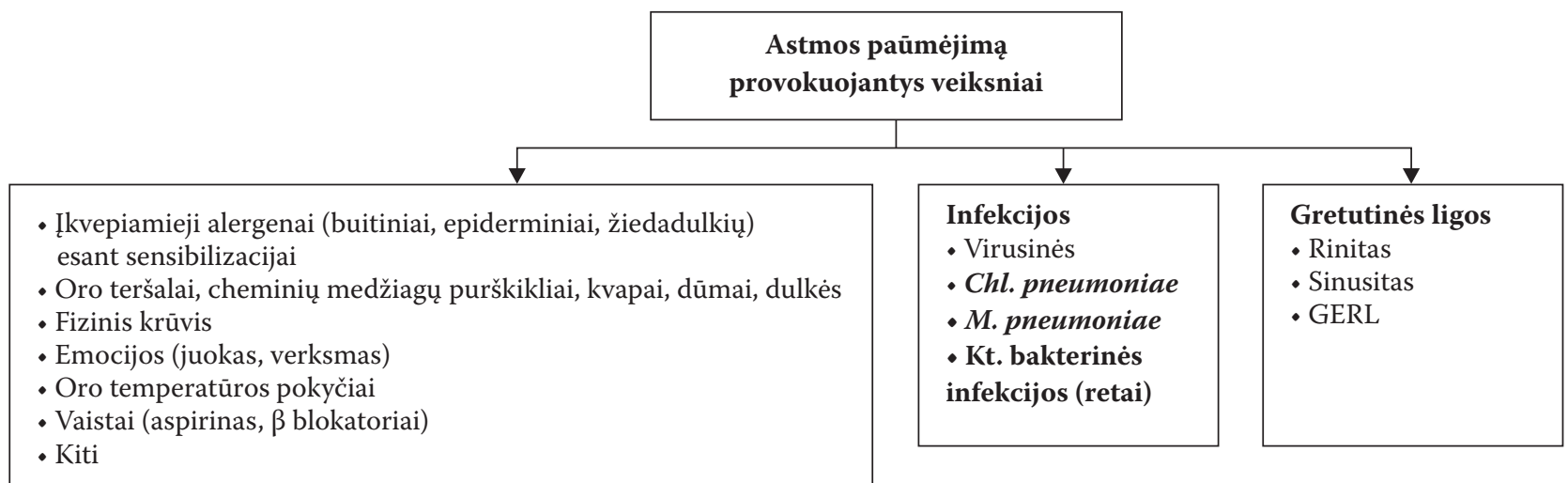

2 pav. ASTMOS PAŨMĖJIMĄ PROVOKUOJANTYS VEIKSNIAI 
1 lentelè. PATOFIZIOLOGINIUY MECHANIZMỤ, SUDARANČIIC SALLYGAS UŽDEGIMUI PLISTI IŠ VIRŠUTINIU KVËPAVIMO TAKU | APATINIUS IR SKATINTI BRONCHU REAKTYVUMO DIDĖJIMA SERGANT ASTMA, APIBENDRINIMAS

- Citokinų, uždegimo mediatorių ir chemotaksinių veiksniu plitimas i apatinius kvejpavimo takus sukelia sinobronchinio reflekso mechanizmą (pasunkina ligos eigą, didindami bronchų reaktyvumą ir sukelia bronchospazmą).

- Suaktyvejusi autonominès nervų sistemos stimuliacija sukelia ūminị bronchospazmą.

- Dèl viršutinių kvėpavimo takų obstrukcijos priverstinis alsavimas pro burną išdžiovina apatinius kvépavimo takus.

- Ančiuose esanti (ypač lètinio uždegimo metu) mikroflora gamina toksinus, kurie sukelia dalinę beta adrenerginių receptorių blokadą.

- Sumažejusi NO koncentracija skatina bronchų reaktyvumo padidèjimą.

mis, - itin opi problema. Tokiais atvejais reiketu paieškoti lètinès C. pneumoniae ir M. pneumoniae infekcijos ịrodymų. Jautriausias šių intraląstelinių mikroorganizmų nustatymo metodas yra PCR. Serologiniai lètinès infekcijos kriterijai nèra pakankamai gerai apibrèžti. Laikoma, kad lètinę infekciją rodo IgG ir IgA klasès antikūnų padidejjimas kartu su lètinès ligos, pavyzdžiui, lètinio bronchito ar nuolatinès astmos, simptomais. Nustatyta, kad IgA klasès antikūnų atsiranda reinfekcijos ir lieka lètinès infekcijos metu.

Buvo iškelta prielaida, kad kortikosteroidų vartojimas astmai gydyti ir gali būti laidas tarp lètinès $C$. pneumoniae ir M. pneumoniae infekcijos bei persistuojančios astmos. Kortikosteroidai skatina imunini atsaką iš Th1 tipo pereiti i Th2 ir taip gali labai pabloginti netipiniais sukèlejais užsikrètusio organizmo gebejjimą sunaikinti intraląstelinius patogenus, kadangi tam reikalingas Th1 tipo imuninis atsakas. Be to, nustatyta, kad kortikosteroidai persistuojančias netipines bakterijas gali iš naujo suaktyvinti ir jos pereina $\mathfrak{i}$ aktyvaus augimo fazę: taip didejant prouždegimo citokinų gamybai toliau stiprëja uždegimas astma sergančių ligonių kvẻpavimo takuose [27].

Üminei $M$. pneumoniae infekcijai gydyti rekomenduojamas 7-14 d. makrolidų ar tetraciklinų kursas, jo paprastai ir užtenka. Tuo tarpu ūminè C. pneumoniae sukelta kvejpavimo takų infekcija po standartinio 7-14 d. gydymo makrolidais ar tetraciklinais kurso dažnai atsinaujina, todèl jos atvejais rekomenduojamas 3 savaičiuc nepertraukiamas gydymas makrolidais [28]. Esant lètinès $C$. pneumoniae infekcijos įrodymų, rekomenduojamas ne trumpesnis kaip 6 savaičių antibakterinis gydymas makrolidais [21].

\section{ASTMA IR SINUSITAS}

Apie astmos ir sinusito ryši kalbama daug metų. Pirmieji tyrimai, rodę esant ryši tarp viršutinių kvèpavimo takų (nosies, prienosinių sinusų) ir bronchų, buvo atlikti Kratchmer 1870 m. Jis įrodè, kad cheminis kačių ir triušių nosies gleivinès dirginimas gali sukelti bronchospazmą. 1984 m. G. S. Rachelefsky su kolegomis pastebèjo, kad astma sergantiems vaikams diagnozavus ir išgydžius sinusitą, labai sumažejo apatinių kvėpavimo takų simptomų ir pagerejo kvejpavimo funkcija. Vèlesnių tyrimuc rezultatai taip pat buvo panašūs, nesvarbu, ar sinusitas gydytas kliniškai ar chirurgiškai [29, 30].

Patofiziologinių mechanizmų, sudarančių sąlygas uždegimui plisti iš viršutinių kvejpavimo takų ị apatinius ir skatinti bronchų reaktyvumo didejimą astma sergantiems pacientams, apibendrinimas pateiktas 1 lenteleje.

Taigi nėra abejonių, kad sinusitas ir astma glaudžiai susijusios ligos. Itvairių epidemiologinių tyrimų duomenimis, sinusitu serga nuo 12 iki 90 proc. astmos ligonių tad jiems labai svarbu laiku diagnozuoti ir tinkamai antibiotikais gydyti sinusitą.

\section{IŠVADOS}

- Tyrimais įrodyta, kad antibiotikų vartojimas pirmaisiais gyvenimo metais gali būti susijęs su didesne alerginių ligų rizika mokykliniame ir vyresniame amžiuje.

- Daugumą švokštimo epizodų ir astmos paūmèjimú vaikystèje sukelia virusinė infekcija, todèl rutininis antibakterinis astmos paūmejjimų gydymas nereikalingas.

- Švokštimas nėra klasikinis nei mikoplazminès, nei chlamidinés kvejpavimo takų infekcijos simptomas, nors ir galimas, be to, C. pneumoniae ir M. pneumoniae nèra ịprasta astmos paūmẻjimų priežastis, todèl rutiniškai makrolidų grupès antibiotikų švokščiančiam vaikui skirti nederètų.

- Su astmos paūmèjimu susijusių bakterinių ligų, tokiu kaip C. pneumoniae ar M. pneumoniae sukelta kvėpavimo takų infekcija, ūminio ar lètinio sinusito paūmèjimas, atvejais būtinas tinkamas antibakterinis gydymas, todèl jos turètų būti patvirtintos klinikiniais tyrimais.

- Pacientus, kuriu astmos simptomai blogai kontroliuojami gydant geriamaisiais ir inhaliuojamaisiais steroidais didelèmis dozėmis, reikètų nuodugniai ištirti dèl C. pneumoniae ir M. pneumoniae infekcijų.

\section{ROLE OF INFECTIONS AND ANTIBIOTICS IN DEVELOPMENT} AND TREATMENT OF ASTHMA

$$
\begin{gathered}
\text { Vilija Bubnaitiené } \\
\text { Clinic of Child Diseases } \\
\text { Kaunas University of Medicine }
\end{gathered}
$$

Key words: asthma, respiratory tract infections, antibiotics.

Summary. Over the last 30 years the prevalence of asthma and other atopic diseases has increased threatingly all over the world. Another major public health problem is the increasing unnecessary prescription of antibiotics especially in children for treatment of viral or insignificant bacterial infections. There appears to be more and more supportive evidence that increasing use of antibiotics and reduced exposure to bacterial infections in early childhood may lead to the increasing development of asthma and other atopic diseases. Respiratory infections in early childhood, particularly bacterial infections, may protect against atopy. Later on bacterial infections may actually cause asthma or provoke asthma attacks, so must be adequately treated with antibiotics. Antibiotics for asthma patients must not be prescribed routinely. Antibiotics should be given only to those asthma patients with clinical, biological and/or radiological signs of bacterial infection. 